\title{
A Double Label: Learning Disabilities and Emotional Problems among Gifted Children
}

\author{
Hanna David \\ Tel Aviv University, Tel Aviv, Israel \\ hannadav@post.tau.ac.il
}

\begin{abstract}
Keywords: learning disabilities, emotional problems, gifted children, double label, twiceexceptional $(2 e)$ children.
\end{abstract}

\begin{abstract}
Many gifted children are "double labeled", namely in addition of being gifted they are also learning disabled and/or suffer from emotional, social or behavioral problems. This article will present the difficulties gifted children with a double label have to deal with, especially the difficulties in the educational system. Because of the double label the educational team faces a double challenge, in most cases without being equipped with the required knowledge or the support they need. This article will describe three case studies; techniques for intervention with such children and their families will be suggested.
\end{abstract}

\section{Introduction: What is "special education"?}

The term "special education" is usually used when referring to the education of children with learning disabilities, emotional or behavioral problems, severe physical limitations, or difficulties stemming from low cognitive abilities. "Gifted education", on the other hand, is used for children with high cognitive abilities, exceptional talents or achievements, creative children or children who have achieved in areas not related to school learning, such as chess, music, art, etc. However, many children belong to both categories. Some of them suffer from problems or gaps not directly related to their giftedness; the others deal with issues connected in one way or another to their being gifted.

These two categories of "double label gifted" have been summarized as follows [1]:

When people think of a twice-exceptional child, they usually think of someone who's gifted and learning disabled. The "second exceptionality" is typically and educational issue like dyslexia, or sometimes a physiological issue like sensory dysfunction. In other cases, however, a child's second condition is said to be emotional, social or behavioral. These are children described as hard-to-manage, badly behaved, or just plain odd - despite, or perhaps because of, their high intelligence.

Students belonging to the first category, namely, who are both gifted and learning-disabled, have been discussed elsewhere [2]. Such students are quite often not identified as gifted due to the compensation mechanism which helps them to achieve mediocrely in spite of their disability; their high cognitive level compensates for their learning-disability. The student belonging to the second group needs a teacher who will be able to help overcome the student's psychological, emotional, and/or social problem. The teacher standing in front of the classroom faces a huge challenge when having a double-labeled student who belongs to one of these categories. She has to satisfy the educational, social and emotional needs of all students, but experience has proven that most teachers can not satisfy the needs of most gifted students. When in addition the student has some disability or limitation the task becomes impossible. In some countries there are special classes serving the needs of some gifted children [3-5], but these classes do not satisfy the needs of doublelabeled students [6-8]. This article will describe the educational and social difficulties the doublelabeled student faces, and present three case studies of gifted students with learning disabilities and/or emotional problems, as well as the techniques of the interventions with them and their families. 


\section{Theoretical Framework}

\subsection{Gifted students with learning disabilities}

Children with learning disabilities, such as dyslexia or ADHD for example, face enormous difficulties; it is beyond the scope of this article to describe the challenges they have to deal with. Children with a double label, of giftedness and learning disability, suffer twice as much as they not only have to overcome both difficulties: being disabled and not fitting into the class because of being gifted, but also because quite often educators are not familiar with the concept of "gifteddisabled" which might sound contradictory for health- and mental health professionals as well.

The difficulties of double-labeled students start right from the identification for giftedness stage, through being perceived as unmotivated, even lazy because of their mediocre achievements:

Many children with the double label, of giftedness and learning disability - fall between the cracks: on the one hand, they do not receive a gifted education, as their leaning disability prevents them from realizing their potential. They are not even perceived as gifted, because in the giftedness identifications exams they do not get the minimal scores needed for inclusion in the gifted group. On the other hand, because of their actual achievements (though not matching their cognitive abilities), they are high enough to be perceived as regular, average students rather than being disabled. In many cases they are defined as unmotivated students, who "obviously" could have obtained better grades had they tried harder [9].

Many parents and educators believed that "if the child is gifted - she or he will eventually manage". Unfortunately, too many times this is not the case. There is hardly a "happy ending" when a dyslectic child is not treated, even when super-intelligent. In many other cases, even when the dyslectic child has found her or his way in life and has become a successful person - they carry with them their childhood scars, a memory of the insults, the derogatory exclamations and the fragile self-value. Let us look at the following examples.

\subsection{Gifted students with emotional problems}

There are many differences between children with learning disabilities and children who suffer from emotional problems. In most cases it is easier to notice a learning disability than an emotional difficulty, and when not identified - an emotional problem cannot be treated. In addition, any learning disability influences the emotional condition, while it happens quite often that emotional problems - even when severe - are not identified in school especially when the student is considered a good one, even a high achiever, in spite of his emotional problems. Another difference has to do with the parents' reaction when there is suspicion of such a problem: when a teacher, counselor, the school psychologist or any other person notifies the parents that they should diagnose their child for a learning disability, they usually accept the recommendation. On the other hand, when parents are asked to treat their child's emotional problems - many refuse or at least delays it. Another important difference is the parents' level of cooperation: while in cases of a learning disability there are good prospects of success even when the child gets the professional help but a minimal parents' involvement, in most cases of emotional problems driving the child to the therapist, paying for the treatment etc. is just not enough. Without active, full cooperation of the parents in the process prospects of success are very low.

The rate of children with psychological problems is comparatively high in gifted classes. This is a result of three main reasons: 1. Quite often parents would not send their gifted children to special gifted classes; they tend to do it when the child has difficulties in the regular classroom; 2. Many gifted children develop psychological problems because of "not fitting in" or "being out of sync" [10]. 3. Some emotional problems occur more often among the gifted, for example, perfectionism which might be paralyzing $[11,12]$.

Gifted children in regular classrooms might be at-risk [13, 14]. A gifted child tends to vulnerability when having no opportunity to spend time with peers similar to him regarding the cognitive level, and when learning in a system that does not fit to his needs [15]. Social acceptance has to do with adapting school norms, and is dependent on speaking about "age-suitable" subjects 
and avoiding "high" language. A gifted girl or boy might feel difficulties when having to participate in activities they are not interested in, holding back rather than expressing their feelings or thoughts because of knowing they "do not fit" - either linguistically and/or substantially. A gifted child who needs to hold back most of the time might develop behaviors such as day dreaming or abstention. $\mathrm{He}$ or she might become "the clown" and disturb the teachers during classes by making funny noises, joking aloud, make fun of the teacher or of other students. Such behaviors do not result from the giftedness per se, but they might define the gifted child who adopts them as "socially unfit", just "unfit" and the like.

The vulnerable gifted child has high prospects to suffer from emotional stress and social conflicts that require a high level of social adaptation so that the inconvenience would not harm his mental health or his overall functioning [16]. According to her gifted children suffer from a certain level of vulnerability but most of them are capable of using their high intellectual abilities to deal effectively with the challenges. A minority is not capable of doing that; they are the children in risk of eating disorders [17, 18], paralyzing perfectionism [19-23], depression [24, 25], self-harm [26] and even suicide [27, 28].

Four decades of research resulted in a conclusion that gifted children are at a higher risk of adjustment problems then their non-gifted peers, and that giftedness increases the vulnerability level to adaptation problems [29]. One of the explanations to this conclusion was that high level of cognitive abilities of gifted children makes them more sensitive to inter-personal conflicts and thus they feel a higher level of estrangement and stress than their peers [30]. (Many researchers support this opinion [31-36].)

\section{Presentation of the cases and discussion}

\subsection{Students with learning disabilities}

\subsubsection{The case of Aiden}

I first met Aiden when he was 7. He was not diagnosed as dyslectic, but rather as having Attention Deficit Disorder and Hyperactivity. Aiden's family lived about 120 miles from my clinic, thus had I known from the beginning about his dyslexia I had not had accepted him for an intervention at all. I had been aware of the fact that such an intervention - if successful - had to be a long one, and that traveling such a distance on a regular basis would have probably tire both child and parents and eventually result in premature termination [37]. In my experience a successful treatment with a dyslectic child must take at least 2 years - until the child's emotional spine is built. When this happens the child accepts her or his limitations and develops learning motivation in spite of the difficulties, and is willing to rely on permanent educational help suitable to his intellectual level so that she or he will materialize her or his potential, talent an ambitions.

Unfortunately, that was not the case with Aiden. I had agreed to accept Aiden after the intake meeting with his parents and reading all relevant materials they had sent me ahead of time, including all psychological diagnoses and evaluations. Nowhere was it mentioned that he was dyslectic - a fact that I had discovered in my first meeting with him. In most cases even if not diagnosed, the parents have some idea even if not explicit knowledge about a disability as severe as dyslexia their child suffers from. In Aiden's case the parents had never heard of dyslexia before, in spite of being both highly educated - the mother had a PhD degree - so they could not have suspected their child suffered from it. At this stage I knew that had I "dropped the bomb" - tell the parents that I suspected their son had a developmental or learning disability - they would probably dismiss me and give up looking for professional help their son needed so badly. I also knew that I could not tell the parents to have their son re-diagnosed - they had already done that when Aiden was 6 and did not know about problems in diagnosing gifted children with disabilities [38, 39]. Thus I started the treatment sessions with teaching Aiden simple reading strategies, such as word isolations, enlarging the page, doubling the spaces between the lines and the paragraphs, and using magnifying glass for reading. 
The fact that Aiden was very bright enabled me to extend the meetings with him to 75 minutes - which is considered "a meeting and a half". His ADHD was compensated by his very high intelligence; when he was busy with issues that interested him, I did not see any sign of his hyperactivity, and his attention span was exceptionally long for his age. His very good cognitive abilities helped him learn the techniques needed for reading quite fast [40]. Indeed, the reading improvement was less that I had expected, but learning these techniques was much easier for Aiden than for the average dyslectic student. Unlike in my other therapeutic meetings I asked Aiden's father to be present in all meetings so he would learn the techniques and will be able to help his son. As I quickly learnt, the amount of work done at home did not increase, so I had to come in terms with the fact that Aiden's advancement was much slower than if he had practiced reading and writing at home more intensively.

This case study does not have a happy ending. As long as I continued my meetings with Aiden his emotional situation improved every week. However, after 7 weeks Aiden's parents decided to terminate our meetings. They believed that as they had already known "what had to be done" - how to help their son in his reading and writing problems and give an adequate answer to his many interests - they would be able to do it without my help - or anybody's.

For three years I had not heard from Aiden - I sent his parents two mails but received no answer. After 3 years I got a mail from the father saying that Aiden refused to go to school, asking me what to do.

The situation of dropping-out of a gifted student is much more common that what we would have wanted to think [40-45]. Many of these dropouts are learning disabled [46, 47]. The reasons for this situation are the vulnerable self of the gifted disabled student [48-50], lack of support from school [51, 52] because of inability to help the double-labeled students both with her or his difficulties and the high level educational needs stemming from her or his giftedness. The gifted disabled student has also well-developed compensation mechanism (e.g. [53]. Thus: "while the actual achievements of such a child would not be high, they would neither be low enough as is usually expected from a learning disabled child. Average or even mildly low learning achievements are not necessarily an indicator of a learning disability, so that a gifted disabled child would be perceived as having lower abilities than the real ones who are not learning-disabled" [8, p. 2]. A common result is the school team's assumption that the students is getting along; the student, on the other hand, feels very often that she or he are not in the right place, and that they might be more successful out of school.

When having a severe disability a learning disabled child - whether gifted or not - needs help throughout school. Dyslexia is by all means a severe disability which does not "get cured". It does not even get "easier to handle" such as medicated ADHD for example. Thus a substantial part of treating a dyslectic child is maintaining permanent help to both child and family. When such a child has no long-term support prospects of school dropout - whether overt or covert - are very high.

\subsubsection{The case of Guy}

When Guy' parents made an appointment with me they wanted to know as much as possible about dyslexia - the disability their son had been diagnosed with. They had him diagnosed in the first place because of the gap between his low performance, especially in school, and his high level of intelligence observed by everybody who had met him - family members as well as the school stuff.

6-year old Guy had a quick mind, he was easy to get with, eager to please, diligent and highly motivated to succeed. This description was given by the kindergarten's team, where Guy was a student from age 4 to 6; Guy's parents fully agreed with it. The pictures of Guy' shown by his parents, were of a good looking child, with medium build, quite tall for his age, smiling heartedly.

I noticed Guy's high intelligence and hunger to learn right in our first meeting. When I asked him: "do you like math?" he answered: "I like numbers, like shapes, I wish I could have learnt more math and geometry than they teach us in the classroom". In order to help him I 
suggested to his parents that he started taking private lessons with a teacher who had a $\mathrm{PhD}$ in math and a lot of experience teaching young children. I was not sure the teacher had experience with dyslectic students, so I was quite surprised when during the telephone call Guy's father make to the teacher, after mentioning Guy's dyslexia, the teacher said: "Einstein also had dyslexia". And indeed, Guy was thrilled by the opportunity to learn high level math; he was eager to please the teacher but his interest in the learned material was far beyond pleasing. For example: when asked to memorize the multiplication table up to 10 , he did so up to 20 . While for most 6 -year olds it is hard to get used to the 10-minute daily memorization routine, Guy usually begged his parents: "can I get another 10 minutes, please?"

In addition to the math teacher I recommended that the daily routine of homework, which was very tiring for Guy, would stop being the mother's responsibility. Guy's parents hired an outstanding student of linguistics for this task. The mother - having more free time - started doing sports with Guy: jogging, wall climbing and swimming. In addition, every evening one of the parents was reading aloud from a book of Guy's choice for a whole hour. As the books suitable for Guy's cognitive level were far beyond his reading ability, this solution served multiple aims: satisfying Guy's curiosity, enlarging his vocabulary, giving an answer to Guy's curiosity and thirst to learn, as well as tightening the father-son and the mother-son connections.

Thanks to the daily learning routine of learning and reading Guy did not suffer from any psychological effects usually observed among dyslectic children, such as anxiety [54-56], depression [55] or low self-esteem [56]. The intervention took two years, and at age 8 Guy was a strong child, interested in many areas, a good student - in spite of dealing with huge reading problems. He was aided by audio books when possible but mainly leaned on his daily working routine.

\subsubsection{Discussion}

Working with a gifted dyslectic child has to start with the child's self. The child must get help in order to define himself as "child with dyslexia" rather than as "a dyslectic child". When the process takes too long we might switch to the definition: "a gifted child with dyslexia", because unlike the case with gifted who have no disabilities - sometimes the self-value of the dyslectic child is very low, and in order to help him the label "gifted" can play a positive role. The intervention should include encouraging the child to speak about his frustration, anxiety as well as hopes, and help him build inner motivation to succeed in reading and writing, in spite of the difficulties. The parents are senior partners in the process: they must understand that without them no long-term improvement is to be expected, and that their meetings with the therapist and the work they are to do will determine whether the treatment is successful or not. The parents must also accept the fact that no immediate improvement is to be expected, and they ought to transfer to "marathon phase" set long-term goals. The whole family is required to re-adjust regarding their priorities, as helping the dyslectic son takes a substantial amount of money, time and energy. This includes, for example, re-arranging family vacations which must not be too long as the dyslectic child has to work even when there is no school. And last but not least: in spite of the fact that the treatment of a dyslectic child is very demanding and the parents can stop it whenever they wish to, they should wait until the building of their son's emotional spine is ended. Even then educational support will probably be needed as long as the child wishes to materialize his or her potential in spite of this severe disability.

\subsection{Gifted children with emotional problems}

\subsubsection{Eli's case}

Eli was perceived by his mother as "hard to handle" from a very young age. At age 6 he was diagnosed as having just a "mild" ADHD, but the parents started immediately medicating him with Ritalin as they were afraid he would be labeled as "difficult" by the school team. When he was concentrated he could learn at an exceptional pace; at 6 he started playing chess in the municipal chess club and was learning English with a private tutor who help him advance very quickly. 
After a few weeks of school it was clear that the 4 hours of "good behavior" the Ritalin helped Eli to achieve were not enough - the teacher complained about "the impossible behavior of Eli" starting during the fourth lesson; Eli just could not sit down quietly. The teacher demanded that the parents came to meet her at least once a week. During these meetings the scenario never changed: the teacher would count, one by one, each fault, mistake, and misbehavior of Eli that occurred since the last teacher-parents meeting. The teacher would explain the parents time and again that Eli refused to work with his peers and obey to her, quarreled with anybody who disagreed with him, always found reasons why not to do his homework, not to finish the school tasks, and not to bring the learning materials as expected. The parents felt these meetings were useless, but were afraid not to attend because they did not want the teacher to become even angrier at their son. They felt she hated him and it was their duty to try make her less angry if not pleased.

But Eli's problems did not end in school. At home he used to quarrel endlessly with his 2year younger brother. It came to a point that the parents avoided going out with both sons being afraid Eli would shout at his brother, curse him or physically attack him in public. Eli had endless complains and the parents felt they had no way to deal with them. Any time they suggested an activity - Eli tried to manipulate them, suggest doing something else or changing the time of the suggested activity. Even when asking him to be ready for an activity he had suggested, he was never ready on time, and thus they had to choose between being late or cancelling the activity both resulted in one of Eli's anger bursts.

The therapeutic process took a long time and was quite intense. Though I met Eli only once a week, I also met his parents once a week for three years. In addition, I received 2-3 mails from the parents every week - in most cases for solving immediate problems and in some - to help the parents to insist on their opinion in spite of their son's resistance and the school's pressures that jeopardized the treatment. For example: the school used to call the parents in order to report of any "unacceptable behavior" believing that such a call meant punishing Eli. However, for Eli every such call was a prize accompanied by hope that the parent who answered the phone would come to school and take him home. In addition to the therapy I had to help the parents refuse to let the school interfere in their life on a regular basis, as in many cases the school would call the parents up to five times a day! This prevented the parents from having a working routine, harmed their wellbeing and made it impossible to gather strength in order to be able to cope with Eli after school.

As for Eli: during the treatment I was extremely strict with him. On one side - I always prepared the materials he had asked for ahead of time, whether it was a video about endemic species of animals in various continents or countries, or information about the first edition of a book that interested him. On the other - if we were in the middle of watching a video and the meeting time was over - I never agreed to continue even for extra 5 minutes. I helped Eli to learn how to accept the fact that "you cannot have it all". For example: if he chose to sew, he could not draw on the same day.

The process was characterized by many ups and downs, but at the end Eli's behavior did not match the ODD characteristics [57, pp. 462-466]. When helping such a young child the achievement is doubled: 1. Eli was never diagnosed as having ODD, and thus escaped prejudices, assumptions that lead to negative attitudes and hostile judgment of children with ODD [58, 59]. 2. The prognosis of high risk to develop a behavioral disorder, which is the case in a very high rate of untreated children with ODD, had been prevented.

\subsubsection{Discussion}

Eli's case can teach us some lessons about ADHD children with symptoms of ODD whether identified as gifted or not. First, when such children were not diagnosed as having ODD it is best to find a good therapist rather than further diagnosing them. The differences between a "stubborn", "difficult" or "ODD" child are not always significant, but though the first two are considered "normative" the third is not, so it is highly recommended to avoid labeling a child at such a tender age with a label that might do a lot of harm, for example: be prevented from participating in many school activities, sports, etc. Furthermore, while ADHD has become not only 
"legitimate" but also "fashionable" socially, and thus there is no shame - in most cases - to admit of having it and seeking for help - including medication, ODD is still not, parents tend to hide it, which is quite understandable but it also contribute to lower the self-image and the self-value of the child whose disorder is kept as a secret. Thus it is recommended - if possible - to treat it without labeling the child as having it.

But without explaining the parents how severe ODD is the therapist's hands are tied. Some parents might withdraw from the treatment when realizing how deep the problem is, or at least stop cooperating with the therapist. In such cases it should be remembered that killing the delivery person is an expected human reaction. The therapist should remember that without parents' cooperation ODD cannot be treated successfully, so withdrawing from the treatment is not necessarily more harmful than continuing it without the parents' full commitment. Only when the parents have recruited themselves to fight in this battle the treatment can succeed without labeling the child with the stained ODD diagnosis.

\section{Conclusion}

As my article [2] describes a sub-group of "double labeled" student, namely, the gifted student with a learning disability or a physical handicap, the conclusions drown at its end are valid to this article as well.

However, as in this article I have described students with emotional, psychological and social difficulties, there are some more conclusions that should be adapted in order to help the double-labeled student.

- It is highly recommended that all teachers - not only those who are trained for teaching the gifted OR special education learners - will learn about double exceptionality. Thus, even if they are not able to help these students, they will - at least - be able to refer any such student to a suitable counselor, psychologist, and expert of learning disability or even to a psychiatrist, when necessary.

- School headmasters should organize in-service training for the whole team in the three following areas: giftedness, learning-disabilities, and social-emotional-psychological issues. Each session of the training will be headed by an expert in at least one of these areas, some of the sessions will offer the participants the opportunity to ask questions about relevant cases in order to give immediate first help to the needing student.

- All schools should include in its team at least one mental health professional who has both the relevant education and the experience in order to help any double-labeled student referred for help. This expert will also serve as a contact-person for the doublelabeled students who will get out-of-school help and be the coordinator between the student's parents and the professionals who take part in the intervention tailored for her or him.

\section{References}

[1] B. Probst, When your child's exceptionality is emotional: Looking beyond psychiatric diagnosis, 2007. Information on http://www.sengifted.org/archives/articles/when-your-childsexceptionality-is-emotional-looking-beyond-psychiatric-diagnosis.

[2] H. David, The gifted disabled student in the regular and the special classroom, International Letters of Social and Humanistic Sciences. 51 (2015) 19-32.

[3] H. David, E.H. Wu, Gifted education in Hong Kong and Israel: Comparative Study, Australasian Journal of Gifted Education. 21(2) (2012) 81-89.

[4] H. David, Gifted education in the Middle East, in: S. Pfeiffer, E. Shaunessy-Dedrick, M. Foley Nicpon (Eds.), APA Handbook of Giftedness and Talent, American Psychological Association, Washington, DC, 2017. (in press) 
[5] F.J. Mönks, R. Pflüger, Gifted education in 21 European Countries: inventory and perspective, Radboud University, Nijmegen, The Netherlands, 2005. Information on https://www.bmbf.de/pub/gifted_education_21_eu_countries.pdf.

[6] G. Batdal Karaduman, Underachievement in gifted students, International Journal on New Trends in Education and Their Implications. 4(4) (2013).

[7] L.E. Brody, C.J. Mills, Gifted children with learning disabilities: a review of the issues, Journal of Learning Disabilities. 30 (1997) 282-296.

[8] B.J. Gilman et al., Critical issues in the identification of gifted students with co-existing disabilities: the twice-exceptional, Sage Open. 3(3) (2013).

[9] H. David, Learning disabilities, Attention deficit (Hyperactivity) Disorder, and giftedness: Two case-studies, Gifted Education Press Quarterly. 25(3) (2011) 2-9.

[10] L.K. Silverman, The construct of asynchronous development, Peabody Journal of Education. $72(3-4)$ (1997) 36-58.

[11] M. Pyryt, Helping gifted students cope with perfectionism, 2004. Information on http://www.davidsongifted.org/Search-Database/entry/A10459.

[12] M. Shaughnessy, Sylvia Rimm on Perfectionism in the gifted - An interview by SENG's Editor-in-Chief, Michael Shaughnessy, 2010. Information on http://sengifted.org/archives/articles/sylvia-rimm-on-perfectionism-in-the-gifted-an-interviewby-sengs-editor-in-chief-michael-shaughnessy.

[13] K. Kearney, Highly gifted children in full inclusion classrooms, Highly Gifted Children. 12 (4) (1996).

[14] R.S. Persson, Experiences of intellectually gifted students in an egalitarian and inclusive educational system: A survey study, Journal for the Education of the Gifted. 33(4) (2010) 536-569.

[15] W. Roedell, Vulnerabilities of highly gifted children, Roeper Review. 6(3) (1984) 127-130.

[16] J.R. Whitmore, Giftedness, conflict, and underachievement. Allyn and Bacon Inc., Boston, Massachusetts, 1980.

[17] J.A. Leroux, M.A. Cuffaro, Adolescent females and body image: Eating disorders and educational implications, Gifted Education International. 16(1) (2001) 11-19.

[18] J. Sundgot-Borgen, M.K. Torstveit, Prevalence of eating disorders in elite athletes Is higher than in the general population, Clinical Journal of Sport Medicine. 14(1) (2004) 25-32.

[19] M. Adderholt-Elliott, Perfectionism \& Underachievement, Gifted Child Today. 12(1) (1989) 19-21.

[20] H. David, Perfectionism among Ultra-Orthodox Israeli youth, in: T.S. Yamin (Ed.), Proceedings of the Annual Conference of the International Centre for Innovation in Education (ICIE) held in Paris-France (July 1-4, 2008), ICIE, Ulm, Germany, 2009, pp. 705-714.

[21] G.L. Flett et al., Components of perfectionism and procrastination in college students, Social Behavior and Personality. 20(2) (1992) 85-94.

[22] K.L. Speirs Neumeister, Factors influencing the development of perfectionism in gifted college students, Gifted Child Quarterly. 48(4) (2004) 259-274.

[23] D. Willings, Burnout among teachers of the gifted and gifted adults, Gifted Education International. 8(2) (1992) 107-113. 
[24] H. Bénony et al., Lien entre dépression et estime de soi scolaire chez les enfants intellectuellement précoces [Link between depression and academic self-esteem in gifted children], Encephale. 33(1) (2007) 11-20.

[25] S.P. Jackson, J. Peterson, Depressive disorders in highly gifted adolescents, Journal of Secondary Gifted Education. 14(3) (2004) 175-186.

[26] S.M. Wood, L.M. Craigen, Self-injurious behavior in gifted and talented youth: What every educator should know, Journal for the Education of the Gifted. 34(6) (2011) 839-859.

[27] T.L. Cross, J.C. Cassady, K.A. Miller, Suicide ideation and personality characteristics among gifted adolescents, Gifted Child Quarterly. 50(4) (2006) 295-306.

[28] H. David, Suicide threats and suicide attempts among the gifted, Gifted Education Press Quarterly. 29(2) (2015) 7-13.

[29] L. Versteynen, Issues in the social and emotional adjustment of gifted children: what does the literature say?, The New Zealand Journal of Gifted Education. 13(1) (2001) 1-8.

[30] M. Neihart, The impact of giftedness on psychological well-being, Roeper Review. 22(1) (1999) 10-17.

[31] L.N. Grossberg, D.G. Cornell, Relationship between personality adjustment and high intelligence: Terman versus Hollingworth, Exceptional Children. 55 (1988) 266-272.

[32] L.S. Hollingworth, Children above IQ 180, Stanford-Binet, World Book Company, New York, 1942.

[33] P.M. Janos, N.M. Robinson, Psychosocial development in intellectually gifted children, in F.D. Horowitz, M. O'Brien (Eds.), The gifted and talented: Developmental perspectives, American Psychological Association, Washington, DC, 1985, pp. 149-195.

[34] W.C. Roedell, Socioemotional vulnerabilities of young gifted children, Journal of Children in Contemporary Society. 18(3-4) (1986) 17-29.

[35] L.K. Silverman, Personality development: The pursuit of excellence, Journal for the Education of the Gifted. 6(1) (1983) 5-19.

[36] A.J. Tannenbaum, Gifted children: Psychological and educational perspectives, New York, Macmillian, 1983.

[37] H. David, Termination of treatment of gifted disabled students, Gifted Education Press Quarterly. 28(4) (2014) 11-21.

[38] H. David, Why is diagnosing the gifted in Israel so problematic? On the problems of Israeli psychologists in diagnosing gifted children and the difficulties in deciphering such diagnoses, Australasian Journal of Gifted Education. 23(1) (2014) 49-58.

[39] H. David, Diagnosis of the gifted in Israel, Gifted Education International. 30(1) (2014) 5760 .

[40] N.B. Jumani et al., Effectiveness of remedial techniques on the performance of special students in the subject of English, Journal of Language Teaching and Research. 2(3) (2011) 697-704.

[41] H. David, Prevention of dropout of a gifted youth: Case study, Gifted Education Press Quarterly. 28(1) (2013) 9-15.

[42] E. Kaskaloglu, Factors behind gifted dropouts, LAP Lambert Academic Publishing Saarbrücken, Germany, 2010.

[43] M.S. Matthews, Gifted learners who drop out: Prevalence and prevention, in: L.V. Shavinina (Ed.), International Handbook on Giftedness, Springer, New York, 2009, pp. 527-536. 
[44] J.S. Renzulli, S. Park, Gifted dropouts: The who and the why, Gifted Child Quarterly. 44(4) (2000) 261-271.

[45] J. Zabloski, Gifted dropouts: A phenomenological study, PhD Dissertation, Faculty of Education: Liberty University, 2010.

[46] G.G. Bear, K.M. Minke, M.A. Manning, Self-concept of students with learning disabilities: A meta-analysis, School Psychology Review. 31 (2002) 405-427.

[47] R.N. Landis, A.L. Reschly, Reexamining gifted underachievement and dropout through the lens of student engagement, Journal for the Education of the Gifted. 36(2) (2013) 220-249.

[48] C. Barber, C.T. Mueller, Social and self-perceptions of adolescents identified as gifted, learning disabled, and twice exceptional, Roeper Review. 33 (2011) 109-120.

[49] S.M. Baum, C. Cooper, T.W. Neu, Dual differentiation: An approach for meeting the curricular needs of gifted students with learning disabilities, Psychology in the Schools. 38(5) (2001) 477-490.

[50] N. Webb, A. Dietrich, Gifted and learning disabled: A neuropsychologist's perspective, Gifted Education Communicator. 36(3\&4) (2005) 1-4.

[51] E.W. King, Addressing the social and emotional needs of twice exceptional students, Teaching Exceptional Children. 38(1) (2005) 16-20.

[52] M. Wellisch, J. Brown, An integrated identification and intervention model for intellectually gifted children, Journal of Advanced Academics. 23(2) (2012) 145-167.

[53] S. Sansom, Gifted students with learning disabilities: A current review of the literature, Acta Scientiae et Intellectus. 1(1) (2015) 5-17.

[54] J.M. Carroll, J.E. Iles, An assessment of anxiety levels in dyslexic students in higher education, British Journal of Educational Psychology. 76(3) (2006) 651-662.

[55] D. Mugnaini et al., Internalizing correlates of dyslexia, World Journal of Pediatrics. 5(4) (2009) 255-264.

[56] B. Riddick et al., Self-esteem and anxiety in the educational histories of adult dyslexic students, Dyslexia. 5(4) (1999) 227-248.

[57] DSM-5 (2013). Diagnostic and statistical manual of mental disorders, American Psychiatric Association, Washington, DC, 2013.

[58] R.A. Allday et al., The biasing effects of labels on direct observation by preservice teachers, Teacher education and special education. 34(1) (2011) 52-58.

[59] B.B. Lahey et al., Attention deficit disorder with and without hyperactivity: Comparison of behavioral characteristics of clinic referred children, Journal of the American Academy of Child and Adolescent Psychiatry. 26(5) (1987) 718-723. 